\title{
PKM PADA TUKANG OJEK DI KELURAHAN MATANI KECAMATAN TOMOHON TENGAH KOTA TOMOHON
}

\author{
Ignatius Javier C. Tuerah \\ Program Studi Pendidikan Bahasa Inggris, Fakultas Bahasa dan Seni, \\ Universitas Negeri Manado (UNIMA) \\ javierignatius@unima.ac.id
}

\begin{abstract}
Abstrak
Perkembangan zaman yang begitu cepat akibat derasnya arus globalisasi membawa dampak positif pada perkembangan dunia pariwisata, termasuk di Indonesia. Masyarakat Ekonomi Asean sudah mulai diberlakukan sejak akhir 2015 membuat persaingan tenaga kerja semakin ketat. Masyarakat Ekonomi ASEAN (MEA) menuntut pentingnya keahlian para pekerja dari semua sektor. Para tukang ojek tanpa disadari merupakan bagian tak terpisahkan dari perkembangan pariwisata. Permasalahan kemudian muncul ketika disadari bahwa bahasa Inggris merupakan bahasa yang dibutuhkan ketika para tukang ojek hendak melayani para turis asing yang datang ke kota Tomohon. Untuk itu, dilaksanakan suatu pelatihan berbahasa Inggris bagi para tukang ojek di Kelurahan Matani dalam mempersiapkan diri menghadapi para turis asing yang membutuhkan jasa mereka.
\end{abstract}

Kata Kunci: Tukang ojek, pelatihan, Bahasa Inggris.

\section{PENDAHULUAN}

Perkembangan zaman yang begitu cepat akibat derasnya arus globalisasi membawa dampak positif pada perkembangan dunia pariwisata, termasuk di Indonesia. Masyarakat Ekonomi Asean sudah mulai diberlakukan sejak pada akhir 2015 membuat persaingan tenaga kerja semakin ketat. Masyarakat Ekonomi ASEAN (MEA) menuntut pentingnya keahlian para pekerja dari semua sektor. Selain itu pula melihat perkembangan sektor pariwisata yang meningkat pesat di Sulawesi Utara, Kementerian Pariwisata (Kemenpar) mendorong Sulut, khususnya untuk menjadi kawasan destinasi wisata favorit di Indonesia. Perkembangan sektor pariwisata di Manado dan Sulawesi Utara pada umumnya melaju pesat. Hal ini terlihat dari jumlah kunjungan wisatawan mancanegara (Wisman) yang meningkat drastis hingga 449 persen pada Mei 2017 dibandingkan dengan Mei 2016.

Di balik semua perkembangan di atas, masyarakat Sulawesi Utara dituntut untuk mempersiapkan warganya, terutama tenaga kerja dalam berbagai sektor untuk memiliki kompetensi yang dibutuhkan dalam menghadapi persaingan dengan tenaga kerja lain di luar Sulawesi Utara. Salah satu kemampuan dasar yang dibutuhkan adalah kemampuan berbahasa Inggris. Kemampuan berbahasa Inggris merupakan salah satu kemampuan yang sangat menentukan dalam memperoleh lapangan kerja akhirakhir ini. Fenomena inilah yang mendasari munculnya berbagai macam kursus Bahasa Inggris di seluruh wilayah Indonesia juga termasuk di Sulawesi Utara. Kursus Bahasa 
Inggris secara gratis, yang bertujuan untuk meningkatkan kemampuan berkomunikasi bahasa asing dalam menghadapi era Masyarakat Ekonomi ASEAN (MEA).

Tukang ojek di Kelurahan Matani secara keseluruhan memiliki keterbatasan dalam berbahasa Inggris, sehingga sering mengalami kesulitan dalam melayani tamu asing yang ingin menikmati indahnya pariwisata di kota Tomohon. Permasalahan pokok yang mereka hadapi adalah persoalan menunjukkan lokasi dan tawar menawar dalam bahasa Inggris. Jadi intinya para tukang ojek membutuhkan keterampilan berbahasa Inggris. Hal tersebut dikarenakan, banyak penumpang dari kalangan turis yang membutuhkan jasa mereka ketika hendak berwisata di Kota Tomohon.

Mengingat kompleksnya permasalahan tersebut di atas dan disadari bahwa tidak semua permasalahan dapat diselesaikan sekaligus dalam kurun waktu tertentu maka berdasarkan justifikasi dan kesepakatan bersama dengan masyarakat mitra maka dipilih beberapa permasalahan prioritas yang harus diatasi, yaitu:

1. Kurangnya kemampuan berbahasa Inggris para tukang ojek di Kelurahan Matani;

2. Tidak adanya pelatihan/kursus bahasa Inggris bagi tukang ojek di Kota Tomohon dan secara khusus di Kelurahan Matani; dan
3. Biaya kursus bahasa Inggris yang mahal dan sulit untuk dijangkau oleh para tukang ojek.

\section{METODE PELAKSANAAN}

Pelaksanaan pelatihan berbahasa Inggris bagi tukang ojek di Kelurahan Matani, secara garis besar terdiri atas tiga bagian yakni, (1) tahap persiapan, (2) tahap pelaksanaan, (3) analisis hasil pelatihan.

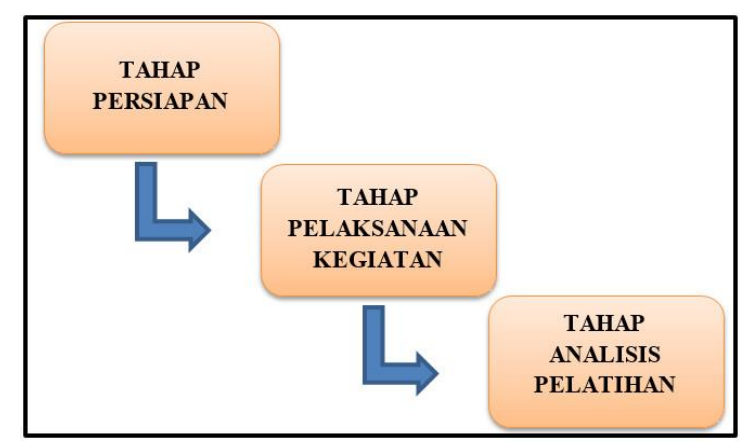

Gambar 1. Tahapan pelaksanaan kegiatan.

Dalam tahap persiapan akan dibuat pretest dan needs survey analysis untuk mengukur sejauh mana pemahaman peserta terhadap bahasa Inggris. Selain itu, dapat diketahui gambaran umum tentang kebutuhan yang sangat dibutuhkan oleh peserta. Tahapan ini akan dibuat dalam tiga pertemuan:

1. Pertemuan 1 akan diisi dengan kegiatan sosialisasi pelatihan;

2. Pertemuan 2, pre-test dan needs survey analysis; dan

3. Pertemuan 3, menganalisa hasil pre-test dan needs survey analysis. 
Pada tahapan pelaksanaan kegiatan, akan dilakukan secara bervariasi dan tentu akan berdasar pada hasil pre-test maupun needs survey analysis. Adapun yang menjadi rancangan kegiatan pada tahapan ini adalah:

1. Pertemuan 4-5, penguasaan vocabulary, praktek pemahaman vocabulary;

2. Pertemuan 6-7, mendengarkan music, pembelajaran vocabulary, grammar, praktek menyanyikan lagu bahasa Inggris, praktek bicara;

3. Pertemuan 8-9, menonton film/video, pembelajaran kebudayaan asing, pembelajaran vocabulary, grammar, praktek bicara; dan

4. Pertemuan 10-11, praktek bicara, full day speaking, English games \& quiz.

Tahap analisis pelatihan dilakukan terakhir untuk mengukur dan mengetahui perkembangan peserta sekaligus merumuskan rekomendasi penting yang berdasar pada hasil pelatihan, dengan rancangan sebagai berikut:

1. Pertemuan 12, post-test; dan

2. Pertemuan 13, pemaparan hasil analisis, pemberian rekomendasi.

Secara umum, keseluruhan rancangan kegiatan pelatihan bahasa Inggris bagi tukang ojek di Kelurahan Matani Kecamatan Tomohon Tengah dapat dilihat pada tabel di berikut ini:
Tabel 2. Rancangan kegiatan pelatihan.

\begin{tabular}{|c|l|c|}
\hline Meeting & \multicolumn{1}{|c|}{ Tahap } & $\begin{array}{c}\text { Alokasi } \\
\text { Waktu }\end{array}$ \\
\hline $1-3$ & Tahap Persiapan & $\begin{array}{c}3 \times 50 \\
\text { minutes }\end{array}$ \\
\hline $4-11$ & $\begin{array}{l}\text { Tahap Pelaksanaan } \\
\text { Kegiatan } 100 \\
\text { minutes }\end{array}$ \\
\hline $12-13$ & $\begin{array}{l}\text { Tahap Analisis } \\
\text { Pelatihan }\end{array}$ & $\begin{array}{c}2 \times 50 \\
\text { minutes }\end{array}$ \\
\hline
\end{tabular}

Keseluruhan proses kegiatan akan diikuti oleh seluruh tukang ojek di Kelurahan Matani Kecamatan Tomohon Tengah. Selaku Mitra dalam kegiatan pelatihan ini, mereka juga nantinya dapat memberikan feed back sesuai dengan apa yang mereka dapatkan dalam pelatihan ini. Keaktifan mereka dalam mengikuti kegiatan, akan berpengaruh besar terhadap hasil yang hendak dicapai.

\section{HASIL DAN PEMBAHASAN}

Pelaskanaan kegiatan PKM bagi tukang ojek di Kelurahan Matani Kecamatan Tomohon Tengah Kota Tomohon dengan bentuk kegiatan: "Peningkatan Keterampilan Berbahasa Inggris bagi Para Tukang Ojek" telah selesai dilaksanakan. Berikut ini penjelasan hasil kegiatan PKM yang dituangkan dalam bentuk hasil kegiatan.

\section{Persiapan}

Dalam tahap persiapan dibuat pre-test dan needs survey analysis untuk mengukur sejauh mana pemahaman peserta terhadap bahasa Inggris. Selain itu, dapat diketahui gambaran umum tentang kebutuhan yang 
sangat dibutuhkan oleh peserta. Tahapan ini dibuat dalam tiga pertemuan:

1. Pertemuan 1 akan diisi dengan kegiatan sosialisasi pelatihan. Dalam pertemuan pertama ini ketua tim pelaksanan PKM menjelaskan kepada peserta maksud dan tujuan dilaksanakannya kegiatan ini. Pada kesempatan ini juga dilaksanakan penyamaan persepsi antara pemateri dan peserta tentang kegiatan yang akan dilaksanakan agar lebih fokus pada maksud dan tujuan kegiatan PKM yang dimaksud;

2. Pertemuan 2, pre-test dan needs survey analysis. Dalam pertemuan kedua ini dilakukan pre-test dan need survey analysis untuk mengetahui tingkat kemampuan berbahasa Inggris dari seluruh peserta. Pre-test ini dilakukan melalui ujian writing dan listening berdasarkan soal penuntun yang sudah disiapkan sebelumnya. Need survey analysis dilakukan sekaligus dalam kegiatan ini untuk mengetahui tingkat kebutuhan dari para peserta; dan

3. Pertemuan 3 , menganalisa hasil pre-test dan needs survey analysis. Dalam pertemuan ketiga ini, seluruh hasil pretest dan needs survey analysis disajikan kepada para peserta. Berdasarkan hasil tersebut kemudian dibuat analis secara bersama-sama antara tim pemateri dan peserta untuk mengetahui kelebihan dan kekurangan masing-masing peserta dan untuk selanjutnya ditindak lanjuti dalam kegaitan pelatihan bahasa Inggris bagi para Tukang Ojek peserta pelatihan.

\section{Pelaksanaan Kegiatan}

Pada tahapan pelaksanaan kegiatan dilakukan secara bervariasi dan berdasar pada hasil pre-test maupun needs survey analysis. Adapun kegiatan pada tahapan ini dilakukan sebagai berikut:

1. Pertemuan 4-5, penguasaan vocabulary, praktek pemahaman vocabulary. Pertemuan keempat dan kelima ini dilaksanakan berdasarkan rekomendasi yang telah diperoleh berdasarkan hasil pretest maupun needs survey analysis yang sudah dilakukan sebelumnya. Permasalahan pokok yang dihadapi oleh para peserta pelatihan adalah kurangnya penguasaan vocabulary, maka pada pertemuan ini pelatihan difokuskan pada kegiatan penguasaan vocabulary. Oleh tim pelaksana para peserta dibagikan lembaran berisi kata-kata dalam bahasa Inggris dan kemudian dalam waktu 5 menit mereka disuruh menghafal katakata tersebut. Setelah 5 menit kemudian para peserta diminta untuk menyebutkan kata-kata bahasa Inggris beserta artinya yang telah mereka hafal tadi. Setelah semua peserta mendapat kesempatan, kemudian oleh tim ditanyakan kepada peserta menurut pendapat mereka mana kata yang mudah dihafal dan yang sulit untuk dihafal. Setelah 
kegiatan tersebut kemudian dilanjutkan dengan praktek pemahaman vocabulary dengan meminta para peserta untuk menuliskan sebanyak mungkin kata bahasa Inggris beserta artinya yang mereka kuasai. Setelah selesai kemudian kegiatan di akhiri dengan memberikan peserta kata-kata bahasa Inggris yang harus mereka hafal untuk pertemuan selanjutnya;

2. Pertemuan 6-7, mendengarkan music, pembelajaran vocabulary, grammar, praktek menyanyikan lagu bahasa Inggris, praktek bicara. Dalam pertemuan ke-enam dan ke-tujuh ini para peserta dihantar untuk mendengarkan lagulagu popular berbahasa Inggris. Lewat kegaitan ini diharapkan para peserta mengalami peningkatan dalam listeningnya. Setelah itu juga para peserta diminta untuk menuliskan kata-kata yang mereka anggap sulit dan mencari artinya di kamus. Akhirnya setelah selesai kemudian dilanjutkan dengan bagian pemaparan tentang grammar structure untuk memberikan pemahaman kepada peserta tentang stuktur kalimat bahasa Inggris yang baik dan benar;

3. Pertemuan 8-9, menonton film/video, pembelajaran kebudayaan asing, pembelajaran vocabulary, grammar, praktek bicara. Dalam pertemuan ke-delapan dan ke-sembilan ini para peserta akan diajak untuk menonton film/video berbahasa Inggris untuk membiasakan indra pendengaran mereka dengan bahasa Inggris. Selain itu juga dalam pertemuan ini diputar video-video kebudayaan asing berbahasa Inggris untuk memberikan pemahan kepada peserta tentang cara berbicara bahasa Inggris yang baik dan bagaimana mempraktekkannya dalam kehidupan sehari-hari. Selain itu, peserta juga dapat mempelajari dan memahami kebiasaan turis asing yang sering sangat berbeda dengan kebudayaan lokal; dan

4. Pertemuan 10-11, praktek bicara, full day speaking, English games \& quiz. Dalam pertemuan sepuluh dan sebelas ini difokuskan pada praktek bicara bahasa Inggris. Oleh karena itu peraturan penting dalam pertemuan ini adalah semua peserta wajib berbahasa Inggris. Para peserta diajak untuk berbicara bahasa Inggris entah dengan pemateri maupun dengan sesama peserta. Bagian ini bertujuan untuk meningkatkan kepercayaan diri peserta dalam berbicara bahasa Inggris. Selain itu dalam pertemuan ini agar para peserta lebih bersemangat, maka dilakukan English game dan quiz yang menarik.

\section{Tahap Analisis Hasil Pelatihan}

Tahap analisis pelatihan dilakukan terakhir untuk mengukur dan mengetahui perkembangan peserta sekaligus merumuskan rekomendasi penting yang berdasar pada hasil pelatihan. 
1. Pertemuan 12, post-test. Pada pertemuan keduabelas ini dilakukan post-test. Post-test ini merupakan bagian terakhir untuk mengevaluasi perkembangan para peserta pelatihan dalam kemampuan mereka berbahasa Inggris. Dalam pertemuan ini para peserta di tes kemampuan writing, listening dan speaking. Hasil post test memperlihatkan perkembangan signifikan dari seluruh peserta dalam kemampuan berbahasa Inggris; dan

2. Pertemuan 13, pemaparan hasil analisis, pemberian rekomendasi. Dalam pertemuan teakhir ini tim pemateri memberikan hasil analisis kepada seluruh peserta sekaligus memberikan rekomendasi dari keseluruhan hasil yang telam mereka capai.

\section{KESIMPULAN DAN SARAN}

\section{Kesimpulan}

Hasil kegiatan PKM pada Tukang Ojek di Kelurahan Matani Kec. Tomohon Tengah Kota Tomohon bisa disimpulkan sebagai berikut:

1. Adanya semangat yang tinggi dari para peserta untuk mengembangkan kemam- puan mereka dalam berbahasa Inggris; dan

2. Ada peningkatan yang sangat signifikan dari para peserta dalam penguasaan vocabulary, listening, writing dan speaking sehingga mereka semua memperoleh rekomendasi yang baik dan siap mempraktekan Bahasa Inggris yang sudah mereka pelajari.

\section{Saran}

1. Perlu adanya pelatihan-pelatihan lanjut bagi bagi para tukang ojek agar mereka bisa mengikuti kegiatan berbahasa Inggris; dan

2. Perlu dukungan tenaga dan dana dari pemerintah dalam melakukan pelatihan-pelatihan sejenis bagi para tukang ojek.

\section{KEPUSTAKAAN}

Marsono. 2005. Seminar Sehari Pengajaran Bahasa Inggris What Went Wrong With English Language Teaching in Indonesia. Dalam: Suhanto Kastaredja. Implementasi Strategi Kognitif dalam Pembelajaran Speaking of Recount Text di SMA. Program Pascasarjana Teknologi Pembelajaran Universitas PGRI Adi Buana Surabaya. 